\title{
GLOSA
}

Ewa Pierzchała

epierzchala@uni.opole.pl

orcid.org/0000-0001-7320-3894

Uniwersytet Opolski

pl. Kopernika 11a

45-040 Opole

\section{Glosa do uchwały Wojewódzkiego Sądu Administracyjnego w Poznaniu z dnia 3 lipca 2020 r., sygn. akt III SA/Po 261/20. Dofinansowanie na zabytek nieruchomy znajdujący się w innej gminie}

Commentary on the resolution of the Provincial Administrative Court in Poznań of $3^{\text {rd }}$ July 2020, III SA/Po 261/20. Subsidy

Summary: The thesis of the resolution issued by the Provincial Administrative Court in Poznań is correct, although incomplete. Against the background of the issues contained in this thesis, a problem emerged related to the financing of an immovable monument located in another commune, owned by a local government unit other than the one in which the monument is located. In such a case, the commune, despite the fact that the monument is not on its territory, is responsible for financing renovation and conservation works to the monument as part of owner care. Additionally, it has the right to receive a subsidy pursuant to Art. 81 of the Act on the Protection of Monuments and the Guardianship of Monuments from the commune that has registered this monument in its records. It should therefore be emphasized that financing the protection and care of immovable monuments has two criteria. The first is the location of the immovable monument, and the second is the legal title 


\section{GLOSA}

Ewa Pierzchała

to the monument. The first entitles one to receive a subsidy, while the second obliges one to finance these activities from one's own funds. A commune that is the owner of an immovable monument on its territory will be deprived of the possibility of subsidizing the monument using the above-mentioned process. In turn, a commune responsible for a monument located in another commune will be able to finance its care from two sources, from subsidies and from its own resources.

Keywords: monument, immovable monument, grant, financing

Streszczenie: Teza uchwały Wojewódzkiego Sądu Administracyjnego w Poznaniu jest jak najbardziej słuszna. Na tle problematyki zawartej opracowaniu pojawił się problem związany $z$ finansowaniem zabytku nieruchomego znajdującego się $w$ innej gminie, będącego własnością jednostki samorządu terytorialnego innej niż ta, w której zabytek się znajduje. W takim przypadku gmina, mimo że zabytek nie znajduje się na jej terenie, musi sfinansować prace remontowo-konserwatorskie zabytku w ramach opieki właścicielskiej. Dodatkowo ma prawo do otrzymania dotacji na podstawie art. 81 ustawy o ochronie zabytków i opiece nad zabytkami z gminy, która ma ten zabytek w swojej ewidencji. Należy zatem podkreślić, że finansowanie ochrony i opieki nad zabytkami nieruchomymi zależy od dwóch kwestii: lokalizacji pomnika nieruchomego oraz tytułu prawnego do zabytku. Lokalizacja uprawnia do otrzymania dotacji, tytuł prawny do zabytku natomiast zobowiązuje do sfinansowania działań z własnych środków. Gmina będąca właścicielem zabytku nieruchomego na swoim terenie zostaje niejako pozbawiona możliwości dofinansowania ww. zakresu. Z kolei posiadając zabytek w innej gminie, będzie mogła sfinansować opiekę nad nim z dwóch źródeł: $z$ dotacji oraz ze środków własnych.

Słowa kluczowe: zabytek, nieruchomy zabytek, dotacja, dofinansowanie

\section{Wprowadzenie}

Ochrona i opieka nad zabytkami nieruchomymi w Polsce mają rozbudowany system środków prawnych o bardzo złożonym charakterze ${ }^{1}$. Są to środki zarówno administracyjne, takie jak: wpis do rejestru zabytków, kontrola stanu zachowania

1 Por. J. Sługocki, Opieka nad zabytkiem nieruchomym. Problemy administracyjnoprawne, wyd. 2, Wolters Kluwer Polska, Warszawa 2017, s. 256 i n. 
i przeznaczenia zabytków czy udaremnianie niszczenia i niewłaściwego korzystania z zabytków, jak i środki finansowe, takie jak: dotacje na prace konserwatorskie, restauratorskie i roboty budowlane przy zabytkach. Jedne i drugie środki mają swoje źródło w przepisach ustawy z dnia 23 lipca 2003 r. o ochronie zabytków i opiece nad zabytkami (dalej u.o.z.), a także w aktach prawa miejscowego, stanowionego przez jednostki samorządu terytorialnego. Warto podkreślić, że kluczowe znaczenie ma rozróżnienie pojęć „ochrona zabytków” $i$ „opieka nad zabytkami”3. Pojęcia te mają swoje definicje legalne $w$ art. 4 i 5 u.o.z. Ochrona zabytków polega na podejmowaniu czynności władczych przez organy administracji publicznej, natomiast opieka nad zabytkami, polegająca na utrzymaniu ich we właściwym stanie technicznym, należy do właścicieli i użytkowników zabytków ${ }^{4}$. W niniejszym opracowaniu, z uwagi na zakres tematyki objętej glosowaną uchwałą, uwaga zostanie skoncentrowana przede wszystkim na zagadnieniach ze sfery finansowej opieki nad zabytkami.

System finansowania opieki nad zabytkami został określony w art. 71-83au.o.z. Normy te regulują zasady przyznawania dotacji na sfinansowanie prac konserwatorskich, restauratorskich i robót budowlanych przy zabytku wpisanym do ewidencji lub rejestru zabytków. Należy zgodzić się z tezą, że „w praktyce aspekt finansowania opieki nad zabytkami stanowi jeden z najważniejszych elementów procesu realizacji określonych w u.o.z. zadań i obowiązków”. Odbywa się on w sposób samofinansujący przez podmioty do tego zobowiązane lub przy wykorzystaniu środków zewnętrznych pochodzących z dotacji udzielanych przez podmioty zobowiązane (zob. art. 71 i 72 u.o.z.).

Zakres finansowania jest ograniczony zakresem podmiotowym i przedmiotowym, a także zdolnością finansową wyżej określonych podmiotów ${ }^{6}$. Komentowana uchwała Wojewódzkiego Sądu Administracyjnego w Poznaniu z dnia 3 lipca 2020 r., sygn. akt III SA/Po 261/20, dotyczy przede wszystkim przedmiotowych granic opieki nad zabytkami, związanych z przekazaniem środków finansowych na prace konserwatorskie, restauratorskie i roboty budowlane przy zabytku. Istota problematyki poruszanej w uchwale WSA zasadniczo sprowadza się do ustalenia, w jakich warunkach gmina może dotować bądź finansować działania związane z opieką nad zabytkami nieruchomymi. Czy wpływ na finansowanie ma położenie zabytku, czy tytuł prawny posiadacza?

2 Ustawa z dnia 23 lipca 2003 r. o ochronie zabytków i opiece nad zabytkami, Dz. U. z 2021 r., poz. 710.

3 Zob. J.Sługocki, op. cit., s. 37 i n.

4 Zob. K. Zalasińska, Prawna ochrona zabytków nieruchomych w Polsce, Wolters Kluwer Polska, Warszawa 2010, s. 197 i n.; K. Zeidler, Prawo ochrony dziedzictwa kultury, Wolters Kluwer Polska, Warszawa 2007, s. 44 in.

5 M. Bidziński, M. Chmaj, Prawne aspekty finansowania opieki nad zabytkami, w: T. Gardocka, J. Sobczak (red.), Prawna ochrona zabytków, Wydawnictwo Adam Marszałek, Szkoła Wyższa Psychologii Społecznej, Toruń 2010, s. 148.

6 Zob. szerzej: M. Cherka (red.), Ustawa o ochronie zabytków i opiece nad zabytkami. Komentarz, Wolters Kluwer Polska, Warszawa 2010, s. 271 in. 


\section{GLOSA}

Ewa Pierzchała

Inaczej rzecz ujmując, można również postawić pytanie: jakie warunki powinien spełnić zabytek, aby można było dofinansować prowadzone przy nim prace konserwatorskie, restauratorskie czy roboty budowlane? $\mathrm{W}$ tym przypadku celem analizy byłoby ustalenie zespołu kryteriów, których spełnienie zagwarantuje możliwość sfinansowania z budżetu gminy prac nad zabytkiem w zakresie ochrony lub opieki. Określenie tych kryteriów powinno opierać się na aktach prawnych wspomnianych na wstępie. Kryteria te mogą mieć charakter zarówno przedmiotowy, jak i podmiotowy.

\section{Teza uchwały}

Uchwała podjęta na podstawie art. 81 ust. 1 u.o.z. nie może być podstawą prawną dofinansowania prac przy zabytku znajdującym się na terenie innej gminy.

Komentowana uchwała dotyczy pośrednio oceny legalności uchwały rady gminy, która podjęła uchwałę zmieniającą swoją uchwałę , na mocy której wykreślono część zdania z pierwotnej wersji w brzmieniu: „znajdującym się na stałe na obszarze Gminy Żelazków". Pierwotna wersja uchwały z dnia 8 sierpnia 2018 r. zakładała, że z budżetu gminy mogą być udzielane dotacje celowe na dofinansowanie prac konserwatorskich, restauratorskich lub robót budowlanych wykonywanych przy zabytku wpisanym do rejestru lub znajdującym się w gminnej ewidencji zabytków, położnych na stałe na obszarze tej gminy, jeżeli zabytek ten łącznie spełnia następujące kryteria: 1) znajduje się w złym stanie technicznym, 2) posiada istotne znaczenie historyczne, artystyczne lub naukowe dla mieszkańców tej gminy9. Kwestionowana zmiana polegała na wykreśleniu wskazanej wyżej części zdania. W pozostałym zakresie, w niezmienionej wersji, zasady nadal obowiązywałyby. Oznaczałoby to, że gmina mogłaby dofinansować prace przy zabytkach położonych na terenie innej gminy niezależnie od tego, kto jest ich właścicielem. Uchwała ta została podważona przez Regionalną Izbę Obrachunkową i rozstrzygnięciem nadzorczym stwierdzono jej nieważność ${ }^{10}$. Organ nad-

\footnotetext{
7 Uchwała z 31 stycznia 2020 r. nr XVI/122/2020 Rady Gminy Żelazków w sprawie zmiany uchwały określającej zasady udzielania dotacji na prace konserwatorskie, restauratorskie lub roboty budowlane przy budynku wpisanym do rejestru lub znajdującym się w gminnej ewidencji zabytków, Dz. Urz. Woj. Wielkopolskiego z 2020 r., poz. 1497.

8 Uchwała z 8 sierpnia 2018 r. nr XXXVII/353/2018 Rady Gminy Żelazków w sprawie określenia zasad udzielania dotacji na prace konserwatorskie, restauratorskie lub roboty budowlane przy budynku wpisanym do rejestru lub znajdującym się w gminnej ewidencji zabytków, Dz. Urz. Woj. Wielkopolskiego z 2018 r., poz. 6398.

9 Zob. ibidem.

10 Uchwała Nr 5/254/2020 Kolegium Regionalnej Izby Obrachunkowej w Poznaniu z dnia 26 lutego 2020 r. w sprawie stwierdzenia nieważności uchwały nr XVI/122/2020 Rady Gminy Żelazków z dnia 31 stycznia 2020 r. w sprawie zmiany uchwały określającej zasady udzielania dotacji na prace konserwatorskie, restauratorskie lub roboty budowlane przy zabytku wpisanym do rejestru lub znajdującym się w gminnej ewidencji zabytków, Dz. Urz. Woj. Wielkopolskiego z 2020 r., poz. 2190.
} 
zoru stwierdził, że „Kolegium RIO wskazało, że akt prawa miejscowego, jakim jest uchwała określająca zasady udzielania dotacji na prace konserwatorskie, restauratorskie lub roboty budowlane dotyczące zabytku wpisanego do rejestru lub znajdującego się w gminnej ewidencji zabytków ma zastosowanie i obowiązuje na obszarze Gminy Żelazków. Tym samym, na podstawie tejże uchwały nie można udzielać dotacji na zabytki, które znajdują się na terenie innych jednostek samorządu terytorialnego"11. Stanowisko to było poddane ocenie sądu na podstawie skargi wniesionej przez radę gminy.

\section{Ocena stanowiska Wojewódzkiego Sądu Administracyjnego w Poznaniu}

Głównym przedmiotem postępowania sądowoadministracyjnego była skarga na rozstrzygnięcie nadzorcze Kolegium Regionalnej Izby Obrachunkowej, stwierdzające nieważność uchwały rady gminy, której treść pośrednio wskazywała na możliwość udzielania dotacji z budżetu gminy na przeprowadzenie prac konserwatorskich, restauratorskich lub robót budowlanych dotyczących zabytku mieszczącego się poza jej obszarem. Sąd administracyjny oddalając skargę rady gminy, stwierdził, że na podstawie art. 81 ust. 1 u.o.z. rada gminy nie może udzielić dotacji na prowadzenie prac konserwatorskich, restauratorskich i robót budowlanych dotyczących zabytku znajdującego się poza obszarem tej gminy. Sąd, powołując się na przepis art. 22 ust. 4-5 u.o.z oraz art. 6 ust. 1 i 7 ust. 1 ustawy z dnia 8 marca 1990 r. o samorządzie gminnym ${ }^{12}$, stwierdzit, że "wobec brzmienia przywołanych przepisów w pełni uzasadnione jest stanowisko organu, że ustawodawca przewiduje udzielanie dotacji przez wszystkie szczeble jednostek samorządu terytorialnego na zasadach ustalonych przez odpowiednie organy stanowiące, że na poszczególny zabytek znajdujący się na terenie danej gminy można otrzymać dotację zarówno z budżetu gminy, powiatu, jak i województwa. W ocenie Sądu wykładnia przywołanych przepisów każe stwierdzić, że zadania własne gminy ograniczają się do zadań o znaczeniu lokalnym, tj. zadań realizowanych na terenie danej gminy"13. Sąd zatem ocenę stanowiska Kolegium RIO oparł przede wszystkim na znaczeniu $\mathrm{i}$ istocie zadań własnych gminy i zasadzie terytorialności. Należy się zgodzić z tezą, że zadania własne gminy mają znaczenie lokalne i co do zasady powinny być wykonywane na terenie gminy. Jednak warto także podkreślić, że jednym z takich zadań jest prowadzenie ewidencji gminnej zabytków znajdujących się na obszarze gminy. Zgodnie z art. 22 ust. 4 u.o.z., wójt prowadzi ewidencję zabytków nieruchomych położonych na terenie danej gmi-

\footnotetext{
11 Ibidem.

12 Ustawa z dnia 8 marca 1990 r. o samorządzie gminnym, Dz. U. z 2021, poz. 735.

13 Uchwała Wojewódzkiego Sądu Administracyjnego w Poznaniu z dnia 3 lipca 2020 r., sygn. akt III SA/ Po 261/20.
} 


\section{GLOSA}

Ewa Pierzchała

ny. Nie ma zatem możliwości, aby zabytek położony na terenie jednej gminy był wpisany do ewidencji zabytków w innej gminnie. Niewątpliwie zarówno wpis do wojewódzkiego rejestru, jak i do gminnej ewidencji stanowi silną podstawę do finansowania prac konserwatorskich, restauratorskich i ewentualnych remontów z budżetu jednostek samorządowych niezależnie od miejsca ich położenia. Dodać należy, że zabytek wpisany do wojewódzkiego rejestru powinien być ujęty w gminnej ewidencji w tej gminie, na obszarze której jest położony ${ }^{14}$.

Niemniej jednak konieczne jest uzupełnienie tych rozważań kwestią rozróżnienia pojęć „samofinansowania prac konserwatorskich, restauratorskich i robót budowlanych dotyczących zabytków" i "udzielania dotacji na prowadzenie prac konserwatorskich, restauratorskich i robót budowlanych dotyczących zabytków"15. Wyjaśnienie tej kwestii sprowadza się do przypadku, w którym gmina może być spadkobiercą, albo obdarowaną zabytkiem nieruchomym położonym na terenie innej gminy, a następnie oddać go w użyczenie, najem czy dzierżawę innemu podmiotowi. Dwa podmioty mogą posiadać do jednego zabytku dwa różne tytuły prawne, np. własność i dzierżawę. Tytuł prawny do tego zabytku wskazywałby, że jest to zabytek gminny, w sensie właścicielskim, ale pozostawiony w posiadaniu innego podmiotu, który też posiadałby tytuł prawny (np. dzierżawa). Status prawny gminy określany byłby na podstawie umowy (np. sprzedaży) bądź orzeczenia sądu (postanowienie o stwierdzeniu nabycia spadku). Natomiast gmina nie występowałaby w tym przypadku jako jednostka samorządu terytorialnego realizująca swoje zadania własne, ponieważ zabytek nie byłby położony na jej terenie. Nie mogłaby także dotować prac konserwatorskich, restauratorskich i robót budowlanych dotyczących takiego zabytku, jeśli inny podmiot korzystałby z niego np. jako dzierżawca lub najemca i jednocześnie zabytek położony byłby poza granicami tej gminy. Zgodnie bowiem z treścią art. 71 ust. 2 u.o.z., „sprawowanie opieki nad zabytkami, w tym finansowanie prac konserwatorskich, restauratorskich i robót budowlanych przy zabytku, do którego tytuł prawny, określony w ust. 1 , posiada jednostka samorządu terytorialnego, jest zadaniem własnym tej jednostki". Norma art. 71 ust. 1 u.o.z. wymienia wiele tytułów prawnych do zabytku, nie ustalając pierwszeństwa żadnego z nich. Norma ta wyraźnie wskazuje na kryterium, według którego należy oceniać dopuszczalność finansowania (niekoniecznie udzielania dotacji) z budżetu gminy prac konserwatorskich, restauratorskich czy robót budowlanych przy zabytku nieruchomym. Tym kryterium jest posiadanie tytułu prawnego do zabytku przez gminę jako jednostkę

14 Wyrok Wojewódzkiego Sądu Administracyjnego w Gdańsku z 22 grudnia 2020 r., sygn. akt II SA/Gd 634/20, LEX nr 3113575; wyrok Wojewódzkiego Sądu Administracyjnego w Białymstoku z 25 maja 2021 r., sygn. akt II SA/Bk 297/21, LEX nr 3199417.

15 Zob. A. Ginter, A. Michalak, Ustawa o ochronie zabytków i opiece nad zabytkami. Komentarz, Wolters Kluwer, Warszawa 2016, art. 71, art. 72, art. 73, art. 74, art. 75, art. 76, art. 77, art. 78, art. 79, art. 80, art. 81, art. 82, art. 82(a), art. 82(b), art. 83. 
samorządu terytorialnego, niezależnie od tego, gdzie dany zabytek jest położony. W przypadku oddania w użyczenie osobie fizycznej zabytku nieruchomego będącego własnością gminy takie dofinansowanie również będzie miało swoją podstawę w art. 71 ust. 2 u.o.z., przy czym „nie ma znaczenia to, czy tytuł prawny do zabytku wynika z umowy nazwanej, czy też nienazwanej lub jednostronnie lub dwustronnej zobowiązującej. Istotne jest jedynie, by treść stosunku zobowiązującego do sprawowania opieki nad zabytkiem była zgodna z ww. normą i interpretowana z uwzględnieniem postanowień art. 353(1) i 65 § 2 k.c."16. Gmina posiadająca tytuł prawny własności do zabytku nieruchomego znajdującego się na terenie innej gminy będzie musiała opiekować się tym zabytkiem jako właściciel, mimo że nie będzie realizowała tego zadania wobec gminnego zabytku w rozumieniu art. 22 ust. 4 u.o.z. jako jednostka samorządu terytorialnego ${ }^{17}$. W ustawie o ochronie zabytków i opiece nad zabytkami oraz w literaturze przedmiotu ze statusem właściciela zabytków wiążą się określone obowiązki ${ }^{18}$. „Właściciele zabytków - osoby fizyczne lub jednostki organizacyjne posiadające tytuł prawny do zabytku wynikający z prawa własności, użytkowania wieczystego, trwałego zarządu, ograniczonego prawa rzeczowego albo stosunku zobowiązaniowego finansują prace konserwatorskie, restauratorskie i roboty budowlane. Działania te wchodzą w zakres sprawowanej przez właścicieli opieki i ochrony nad zabytkiem, polegającej w szczególności na zabezpieczeniu i utrzymaniu zabytku wraz z otoczeniem w jak najlepszym stanie, zgodnie z przepisami u.o.z."19.

Różnica w przekazaniu środków finansowych z tytułu obowiązków właścicielskich, w porównaniu do obowiązków wynikających z realizacji zadań własnych, jest zasadnicza. Sprowadza się ona do ustalenia sytuacji podmiotowej i stosunku prawnego między gminą i podmiotem, wobec którego gmina ma obowiązek dotowania. Stosunek prawny między gminą i podmiotem dotowanym powstaje tam, gdzie podmiot dotowany jest tzw. zewnętrznym podmiotem. Natomiast jeśli zabytek jest własnością gminy, to w przypadku, gdy jest on położony na terenie innej gminy, gmina będąca właścicielem zabytku ma prawo żądać od gminy, do której ewidencji jest wpisany zabytek, dotacji na prace konserwatorskie, restauratorskie i roboty budowlane dotyczące zabytków, na podstawie art. 81 u.o.z. Wówczas te dwie gminy łączy stosunek prawnoadministracyjny, bo są one dla siebie podmiotami niepodporządkowanymi (tzw. zewnętrznymi).

\footnotetext{
16 A. Ginter, A. Michalak, op. cit., art. 71.

17 Por. K. Zalasińska, Ustawa o ochronie zabytków i opiece nad zabytkami. Komentarz, C.H. Beck, Warszawa 2020.

18 Por. J. Sobczak, Między świętym prawem własności, a potrzeba ochrony dziedzictwa narodowego. Nacjonalizacja a rewindykacja, w: T. Gardocka, J. Sobczak (red.) Prawna ochrona zabytków, s. 104-117.

19 A. Ginter, A. Michalak, op. cit., art. 71.
} 


\section{GLOSA}

Ewa Pierzchała

Na marginesie rozważań należy podkreślić, że zabytek nieruchomy nie może być wpisany do ewidencji zabytków prowadzonych przez gminę, na terenie której nie jest położony.

Warto także dodać, że istotą dotacji, zgodnie z art. 126 ustawy z dnia 26 sierpnia 2009 r. o finansach publicznych ${ }^{20}$, są podlegające szczególnym zasadom rozliczania środki z budżetu państwa, budżetu jednostek samorządu terytorialnego oraz z państwowych funduszy celowych przeznaczone na podstawie niniejszej ustawy, odrębnych ustaw lub umów międzynarodowych na finansowanie lub dofinansowanie realizacji zadań publicznych. I chociaż wprost z cytowanej normy nie wynika, że utrzymywanie własnego zabytku nie odbywa się na podstawie dotacji, to w rzeczywistości i w praktyce finansowanie realizacji zadań publicznych sprowadza się do tego, że środkami finansowymi w ramach dotacji wspiera się podmioty tzw. zewnętrzne. W doktrynie prawa przez dotację rozumie się „udzielenie bezzwrotnego wsparcia finansowego ze środków publicznych określonym podmiotom" ${ }^{21}$. Z tak przedstawionego rozumienia pojęcia dotacji wynika, że gmina nie może sobie udzielić bezzwrotnego wsparcia ${ }^{22}$, a tym samym nie może ze sobą nawiązać stosunku prawnego, na podstawie którego takie wsparcie byłoby przekazane.

\section{Podsumowanie}

Teza uchwały Wojewódzkiego Sądu Administracyjnego w Poznaniu jest jak najbardziej słuszna. Na tle problematyki zawartej w tej tezie wyłonił się problem związany z finansowaniem zabytku nieruchomego położonego na terenie innej gminy, będącego własnością jednostki samorządu terytorialnego innej niż ta, na obszarze której zabytek się mieści. W takim przypadku gmina, mimo że zabytek nie leży na jej terenie, musi finansować $w$ ramach opieki właścicielskiej prace remontowe i konserwatorskie zabytku. Dodatkowo ma prawo do otrzymania dotacji na podstawie art. 81 u.o.z. od gminy, która posiada ten zabytek w swojej ewidencji. Należy zatem podkreślić, że finansowanie opieki nad zabytkami nieruchomymi ma dwa kryteria. Pierwsze - to położenie zabytku nieruchomego, a drugie - to kwestia tytułu prawnego do zabytku. Pierwsze uprawnia do otrzymania dotacji, drugie zaś zobowiązuje do finansowania tych działań z własnych środków pieniężnych. Gmina, która jest właścicielem zabytku nieruchomego na swoim terenie, będzie pozbawiona możliwości dotowania we wskazanym wyżej zakresie. Posiadając z kolei zabytek na terenie innej gminy, opiekę nad nim będzie mogła finansować z dwóch źródeł - z dotacji

20 Ustawa z dnia 26 sierpnia 2009 r. o finansach publicznych, Dz. U. z 2021 r., poz. 305.

21 K. Czarnecki, w: Z. Ofiarski (red.), Ustawa o finansach publicznych. Komentarz, wyd. 2, Wolters Kluwer Warszawa 2020, art. 126.

22 Zob. szerzej: K. Gołębiowski, Samorząd terytorialny wobec problemu ochrony zabytków, „Państwo i Prawo" 2000, z. 11. 
Glosa do uchwały Wojewódzkiego Sądu Administracyjnego w Poznaniu... Commentary on the resolution of the Provincial Administrative Court in Poznań...

i ze środków własnych. Rozróżnienie tej sytuacji jest konieczne. Niemniej jednak na tle obowiązującego stanu prawnego może wiązać się z problemami interpretacyjnymi co do określenia sytuacji, w której istnieje podstawa samofinansowania lub dotowania prac przy zabytku.

\section{Bibliografia}

Bidziński M., Chmaj M., Prawne aspekty finansowania opieki nad zabytkami, w: T. Gardocka, J. Sobczak (red.), Prawna ochrona zabytków, Wydawnictwo Adam Marszałek, Szkoła Wyższa Psychologii Społecznej, Toruń 2010.

Cherka M. (red.), Ustawa o ochronie zabytków i opiece nad zabytkami. Komentarz, Wolters Kluwer Polska, Warszawa 2010.

Czarnecki K., w: Z. Ofiarski (red.), Ustawa o finansach publicznych. Komentarz, wyd. 2, Wolters Kluwer, Warszawa 2020.

Ginter A., Michalak A., Ustawa o ochronie zabytków i opiece nad zabytkami. Komentarz, Wolters Kluwer, Warszawa 2016.

Gołębiowski K., Samorząd terytorialny wobec problemu ochrony zabytków, „Państwo i Prawo”, 2000, z. 11.

Sobczak J., Między świętym prawem własności, a potrzeba ochrony dziedzictwa narodowego. Nacjonalizacja a rewindykacja, w: T. Gardocka, J. Sobczak (red.) Prawna ochrona zabytków, Wydawnictwo Adam Marszałek, Szkoła Wyższa Psychologii Społecznej, Toruń 2010.

Sługocki J., Opieka nad zabytkiem nieruchomym. Problemy administracyjnoprawne, wyd. 2, Wolters Kluwer Polska, Warszawa 2017.

Uchwała Nr 5/254/2020 Kolegium Regionalnej Izby Obrachunkowej w Poznaniu z dnia 26 lutego 2020 r. w sprawie stwierdzenia nieważności uchwały nr XVI/122/2020 Rady Gminy Żelazków z dnia 31 stycznia 2020 r. w sprawie zmiany uchwały określającej zasady udzielania dotacji na prace konserwatorskie, restauratorskie lub roboty budowlane przy zabytku wpisanym do rejestru lub znajdującym się w gminnej ewidencji zabytków, Dz. Urz. Woj. Wielkopolskiego z 2020 r., poz. 2190.

Uchwała Wojewódzkiego Sądu Administracyjnego w Poznaniu z dnia 3 lipca 2020 r., sygn. akt III SA/Po 261/20.

Uchwała z 8 sierpnia 2018 r. nr XXXVII/353/2018 Rady Gminy Żelazków w sprawie określenia zasad udzielania dotacji na prace konserwatorskie, restauratorskie lub roboty budowlane przy budynku wpisanym do rejestru lub znajdującym się w gminnej ewidencji zabytków, Dz. Urz. Woj. Wielkopolskiego z 2018 r., poz. 6398.

Uchwała z 31 stycznia 2020 r. nr XVI/122/2020 Rady Gminy Żelazków w sprawie zmiany uchwały określającej zasady udzielania dotacji na prace konserwatorskie, restauratorskie lub roboty budowlane przy budynku wpisanym do rejestru lub znajdującym się w gminnej ewidencji zabytków, Dz. Urz. Woj. Wielkopolskiego z 2020 r., poz. 1497.

Ustawa z dnia 8 marca 1990 r. o samorządzie gminnym, Dz. U. z 2021, poz. 735.

Ustawa z dnia 23 lipca 2003 r. o ochronie zabytków i opiece nad zabytkami, Dz. U. z 2021 r., poz. 710.

Ustawa z dnia 26 sierpnia 2009 r. o finansach publicznych, Dz. U. z 2021 r., poz. 305. 


\section{GLOSA}

Ewa Pierzchała

Wyrok Wojewódzkiego Sądu Administracyjnego w Białymstoku z 25 maja 2021 r., sygn. akt II SA/Bk 297/21, LEX nr 3199417.

Wyrok Wojewódzkiego Sądu Administracyjnego w Gdańsku z 22 grudnia 2020 r., sygn. akt II SA/Gd 634/20, LEX nr 3113575.

Zalasińska K., Prawna ochrona zabytków nieruchomych w Polsce, Wolters Kluwer Polska, Warszawa 2010

Zalasińska K., Ustawa o ochronie zabytków i opiece nad zabytkami. Komentarz, C.H. Beck, Warszawa 2020.

Zeidler K., Prawo ochrony dziedzictwa kultury, Wolters Kluwer Polska, Warszawa 2007. 